INFO ARTIKEL

Riwayat Artikel:

Diterima : 9 Juli 2020

Disetujui : 10 Agustus 2020

\title{
PENDIDIKAN
}

\section{UPAYA GURU GEOGRAFI DALAM MENINGKATKAN HASIL BELAJAR FORMATIF MENGGUNAKAN MODEL PEMBELAJARAN TIPE SCRAMBLE PADA SMA NEGERI 1 MENTEBAH KABUPATEN KAPUAS HULU}

\author{
Rina $^{1}$, Rika Anggela ${ }^{2}$ \\ ${ }^{1,2}$ Program Studi Pendidikan Geografi IKIP PGRI Pontianak. Jalan Ampera No.88 Pontianak \\ $(\nabla)^{1}$ rinac4hy4n1@gmail.com
}

\begin{abstract}
This study aims to improve learning outcomes by using Scramble type learning in Class X of SMA Negeri 1 Mentebah, Kapuas Hulu Regency. The research method is the Classroom Action Research method, which is carried out collaboratively. Samples numbered 41 students. The cycle stage consists of planning the action, implementing the action, observing the action and reflecting on the action. Data collection techniques used were measurement techniques in the form of learning outcomes, direct observation techniques in the form of observation guides, and documentary techniques in the form of photographs, lesson plans and syllabi. Data analysis using the average formula (Mean). The results of the study based on the percentage of teacher observation sheets using Scramble type learning models, in cycle 1 only reached $64 \%$ and in the second cycle the results of teacher observation sheets reached $81 \%$. completeness is $39.02 \%$ and students who are incomplete are $60.98 \%$ with an average value of 68.41 . The first cycle of students is $53.66 \%$ and the total number of students who are not complete is $46.34 \%$ with an average grade of averaging 74.76 . Cycle II students who completed $80.49 \%$ and students who did not complete $19.51 \%$, with an average value of 85.00 . Based on the results of this research that the Scramble type of learning has increased $85 \%$, and has reached the indicator of success
\end{abstract}

Keywords: Scramble Type Learning and Learning Outcomes

\begin{abstract}
ABSTRAK
Penelitian ini bertujuan untuk meningkatkan hasil belajar formatif dengan menggunakan model pembelajaran tipe Scramble Pada SMA Negeri 1 Mentebah Kabupaten Kapuas Hulu. Metode penelitian adalah Penelitian Tindakan Kelas, yang dilakukan secara kolaboratif. Subjek penelitian ini adalah siswa kelas $\mathrm{X}$ berjumlah 41 siswa. Tahapan siklus terdiri dari perencanaan tindakan, pelaksanaan tindakan, pengamatan tindakan dan refleksi terhadap tindakan. Teknik pengumpulan dan alat pengumpulan data yang digunakan adalah Teknik pengukuran berupa soal hasil belajar, Teknik observasi langsung berupa Panduan observasi, dan Teknik dokumenter berupa foto-foto, RPP dan silabus. Analisis data menggunakan rumus rata-rata (Mean).Hasil penelitian berdasarkan persentasi lembar observasi guru dengan menggunakan model pembelajaran tipe Scramble, pada siklus 1 hanya mencapai 64\% dan pada siklus ke II hasil lembar observasi guru mencapai $81 \%$. Hasil perhitngan prasiklus siswa yang tuntas sebesar $39,02 \%$ dan siswa yang tidak tuntas $60,98 \%$ dengan nilai rata-rata sebesar 68,41. Siklus I siswa yang tuntas sebesar 53,66\% dan jumlah siswa yang tidak tuntas sebesar $46,34 \%$ dengan nilai rata-rata sebesar 74,76 . Siklus II siswa yang tuntas $80,49 \%$ dan siswa yang tidak tuntas $19,51 \%$, dengan nilai rata-rata sebesar 85,00. Berdasarkan hasil peneltian ini bahwa pembelajaran tipe Scramble terdadapat peningkatan $85 \%$, dan sudah mencapai indicator keberhasilan.
\end{abstract}

Kata kunci: Pembelajaran Tipe Scramble dan Hasil Belajar 


\section{PENDAHULUAN}

Peningkatan kualitas sumber daya manusia dapat dimulai dengan peningkatan mutu di bidang pendidikan. Mutu dibidang pendidikan dipengaruhi berbagai aspek salah satunya adalah tenaga kependidikan. Peningkatan kualitas dan kuantitas tenaga kependidikan diikuti dengan pembaharuan kurikulum sesuai dengan perkembangan ilmu pengetahuan dan teknologi serta tuntutan zaman yang semakin modern. Salah satu komponen penting dalam dunia pendidikan adalah guru. Pada masa ini guru bukan hanya memiliki peranan dalam memberikan pengetahuan saja namun guru harus dapat memfasilitasi siswa untuk dapat aktif, kreatif, kritis dan inovatif dalam menanggapi semua mata pelajaran yang sedang dipelajarinya bukan hanya itu siswa juga harus dapat mengaitkan pembelajaran dengan kehidupan sehari-harinya dengan berberbekal sarana dan prasarana belajar yang dimilikinya.

Geografi merupakan mata pelajaran yang di dalamnya terdapat banyak materi yang menuntut siswa untuk dapat mengemukakan berbagai fakta dan peristiwa, memberikan argumentasi mengenai kaitan antar konsep dan kaitannya dengan kehidupan seharihari. Dalam pembelajaran Geografi siswa juga mengembangkan daya pikirnya, maka secara tidak langsung siswa harus dapat menghafal dan menganalisis materi, ditambah lagi dengan metode mengajar guru yang lebih banyak menggunakan ceramah dan pemberian tugas, sehingga terkadang ditemui suatu kebosanan dalam diri siswa. Siswa jadi malas bertanya apabila belum memahami materi, siswa sering ngobrol dengan temannya sementara guru menerangkan materi di depan kelas, bahkan siswa tidak mengerjakan tugas yang diberikan, merupakan efek dari kebosanan dan semangat siswa yang menurun. Hal tersebut tentu saja berdampak pada hasil belajarnya.

Berdasarkan hasil observasi peneliti di Kelas X (Sepuluh) SMA Negeri 1 Mentebah Kabupaten Kapuas Hulu, diperoleh informasi masih ada siswa malas mencatat materi yang dituliskant guru di papan tulis, ada siswa yang masih mengobrol dengan temannya dan tidak memperhatikan guru menjelaskan di depan kelas. Siswa juga tampak tidak bersemangat saat kegiatan tanya jawab, namun saat guru keluar kelas untuk mengambil alat pembelajaran yang tertinggal, suasana kelas malah sangat ribut oleh suara-suara siswa sehingga mengganggu kegiatan belajar di kelas sebelahnya. Hal ini terjadi hampir di semua kelas X khususnya pada mata pelajaran Geografi dengan materi Pengantar Geografi. Gejala tersebut disebabkan karena dalam mengajar, guru masih menggunakan metode yang tidak bervariasi sehingga guru lebih monoton disaat proses pembelajaran berlangsung. Pembelajaran diawali dengan guru memberikan informasi tentang tata tertib saat proses belajar berlangsung, absensi, kemudian guru langsung menyampaikan materi yang akan disampaikan dengan mencatat di papan tulis. Pembelajaran seperti ini, mengakibatkan siswa tidak bergairah untuk mengikuti pelajaran yang sedang berlangsung, dan mereka menjadi bermalas-malasan. Selanjutnya berdasarkan hasil belajar (ulangan harian) pada mata pelajaran Geografi, menunjukkan bahwa ada kelas yang siswanya belum mencapai ketuntasan (KKM). Adapun data nilai hasil belajar siswa dapat dilihat pada Tabel berikut :

Tabel 1. Hasil Ulangan Harian Kelas X SMA Negeri 1 Mentebah

\begin{tabular}{|c|c|c|c|c|c|c|}
\hline & \multirow{2}{*}{ No } & Kelas & \multirow{2}{*}{$\begin{array}{c}\text { Jumlah } \\
\text { siswa }\end{array}$} & \multicolumn{2}{|c|}{$\begin{array}{c}\text { Hasil ulangan } \\
\text { harian }\end{array}$} & \multicolumn{2}{|c|}{$\begin{array}{c}\text { Standar } \\
\text { ketuntasan }\end{array}$} \\
\cline { 4 - 7 } & & Tuntas & $\begin{array}{c}\text { Tidak } \\
\text { tuntas }\end{array}$ & $\begin{array}{c}\text { Nilai } \\
\text { rata- } \\
\text { rata }\end{array}$ & KKM \\
\hline 1. & X A & 36 & 26 & 8 & 76,78 & 75 \\
\hline 2. & X B & 41 & 16 & 25 & 68,41 & 75 \\
\hline 3. & X C & 35 & 26 & 9 & 75,83 & 75 \\
\hline
\end{tabular}

Berdasarkan Tabel di atas, diketahui kelas XA mencapai ketuntasan sekitar 72,22\% dengan nilai rata-rata kelas 76,78, kelas XB 39,02\% dengan nilai rata-rata kelas 70,57 dan kelas XC $72,22 \%$ dengan nilai rata-rata kelas 68,41 . Nilai KKM untuk mata pelajaran Geografi di Kelas Kelas X SMA Negeri 1 Mentebah Kabupaten Kapuas Hulu adalah 75. Berdasarkan nilai yang diperoleh dari data di atas, nampak bahwa kelas XB banyak siswa yang tidak tuntas, dengan nilai rata-rata kelas masih tidak memenuhi nilai KKM. Oleh karena itu, kelas yang perlu ditindak lanjuti 
atau yang perlu adanya tindakan adalah kelas XB.

Melihat fakta-fakta yang ditemukan di sekolah terlihat perlu adanya usaha untuk dapat menyelesaikan permasalahan yang terkait dengan hasil belajar. Menurut (Purwanto, 2010) disebutkan "Hasil belajar termasuk komponen pendidikan yang harus disesuaikan dengan tujuan pendidikan, karena hasil belajar diukur untuk mengetahui ketercapaian tujuan pendidikan melalui proses belajar mengajar". (Sudjana, 2010) menyebutkan fungsi hasil belajar adalah sebagai: "Alat untuk mengetahui tercapai tidaknya tujuan instruksional, umpan balik bagi perbaikan proses belajar mengajar, dasar dalam menyusun laporan kemajuan belajar siswa kepada para orang tuanya". Untuk itu hasil belajar siswa merupakan suatu ukuran keberhasilan guru dalam memberikan pembelajaran sehingga ketika suatu kelas memiliki hasil belajar dibawah standar yang seharusnya maka perlu adanya perbaikan.

Faktor-faktor yang mempengaruhi hasil belajar formatif dapat menghambat keberhasilan siswa dalam pencapaian pembelajaran selanjutnya. Menurut (Djamarah, 2002) secara garis besar faktor yang mempengaruhi hasil belajar siswa meliputi : 1)faktor lingkungan, terdiri dari lingkungan alami dan lingkungan sosial budaya; 2) faktor instrumental, terdiri dari kurikulum, program, sarana dan fasilitas, dan guru; 3) kondisi fisiologis; 4) kondisi psikologis, terdiri dari minat, kecerdasan, bakat, motivasi dan kemampuan kognitif. Berdasarkan hasil observasi, peneliti melihat faktor yang kaitannya dengan guru harus mendapatkan perhatian. Proses pembelajaran berlangsung dengan baik, jika terjadi suatu interaksi antara guru dan siswa (Lisa, Ariesta, \& Purwadi, 2018). Dalam proses pembelajaran di kelas, siswa tidak hanya berinteraksi dan mendapatkan informasi dari guru tetapi juga dari teman-temannya. Bersama teman sekelasnya siswa dapat berbagi informasi dan berdiskusi tentang suatu permasalahan dan memecahkannya bersama-sama. Oleh karena itu, dalam menyajikan mata pelajaran Geografi, seorang guru harus memilih metode, langkah maupun strategi mengajar yang tepat sehingga siswa lebih bertanggung jawab, bekerjasama dan aktif dalam kegiatan belajarnya. Ketepatan guru dalam memberikan variasi cara, langkah maupun strategi mengajar pada penyampaian materi, akan dapat merangsang siswa untuk terlibat dalam kegiatan belajar mengajar sehingga akan berdampak pada hasil belajarnya.

Salah satu alternatif solusi yang dapat diberikan dalam memecahkan permasalahan tersebut dengan menggunakan metode pembelajaran tipe Scramble. Menurut (Huda, 2013) mengatakan bahwa: "Scramble merupakan salah satu metode pembelajaran yang dapat meningkatkan konsentrasi dan kecepatan berpikir siswa". Pembelajaran kooperatif tipe Scramble adalah sebuah metode yang menggunakan penekanan latihan soal berupa permainan yang dikerjakan secara berkelompok yang memerlukan adanya kerjasama antar anggota kelompok dengan berfikir kritis sehingga dapat lebih mudah dalam mencari penyelesaian soal. Pembelajaran ini memberikan lembar soal dan lembar jawaban yang disertai dengan alternatif jawaban yang tersedia. Siswa diharapkan mampu mencari jawaban dan cara menyelesaikan soal. Metode Pembelajaran Scramble memberikan kelebihan dimana Setiap anggota kelompok bertanggung jawab atas segala sesuatu yang dikerjakan dalam kelompoknya, metode pembelajaran ini akan memungkinkan siswa untuk belajar sambil bermain, selain itu dapat menimbulkan kegembiraan dan melatih keterampilan tertentu. Materi yang diberikan melalui salah satu metode permainan ini biasanya mengesankan dan sulit untuk dilupakan, sifat kompetitif dalam metode ini dapat mendorong siswa berlomba-lomba untuk maju.

Metode Scramble juga dapat memupuk rasa solidaritas dalam kelompok. Metode scramble juga dapat meningkatkan aktivitas dan prestasi belajar (Lestari \& Sriwanto, 2015).

\section{METODE PENELITIAN}

Metode penelitian ini menggunakan metode Classroom Action Research, dengan bentuk penelitian yang bersifat reflektif (Sugiyono, 2018). Subjek dalam penelitian siswa kelas XB SMA Negeri 1 Mentebah Kabupaten Kapuas Hulu tahun ajaran 2016/2017 dengan jumlah siswa 41 orang, terdiri dari 23 orang siswa laki-laki dan 18 orang siswa perempuan.Penelitian menggunakan siklus yang setiap tahapan siklus terdiri dari perencanaan tindakan, pelaksanaan tindakan, pengamatan tindakan dan refleksi terhadap tindakan. Teknik pengumpulan data yang digunakan adalah teknik pengukuran dengan alat pengumpul data berupa soal hasil belajar, teknik observasi langsung dengan alat pengumpul datanya panduan observasi, dan teknik dokumenter dengan alat pengumpul datanya foto-foto, RPP dan silabus. Selanjutnya data di analisis dengan menggunakan 
analisis data model Miles dan Huberman yang dikenal dengan Interactive Model dan rumus rata-rata (Mean).

\section{HASIL DAN PEMBAHASAN}

Penelitian dilaksanakan di kelas XB SMA Negeri 1 Mentebah Kabupaten Kapuas Hulu tahun ajaran 2016/2017. Kegiatan pratindakan dilakukan untuk mengawali penelitian tindakan kelas, dengan tujuan untuk mengetahui hasil belajar awal siswa pada materi pengantar geografi yang kaitannya dengan konsep, pendekatan, prinsip serta aspek geografi. Kegiatan pratindakan dilakukan oleh Peneliti dengan berkolaborasi dengan guru meliputi perencanaan pelaksanaan pembelajaran, mengadakan evaluasi untuk mengetahui sejauh mana pemahaman dan pengetahuan siswa pada materi konsep, pendekatan, prinsip serta aspek geografi yang disampaikan.

Siklus I dimulai dengan perencanaan. Perencanaan ini mengacu pada RPP yang digunakan oleh peneliti dan guru yang sebelumnya mengacu pada silabus.

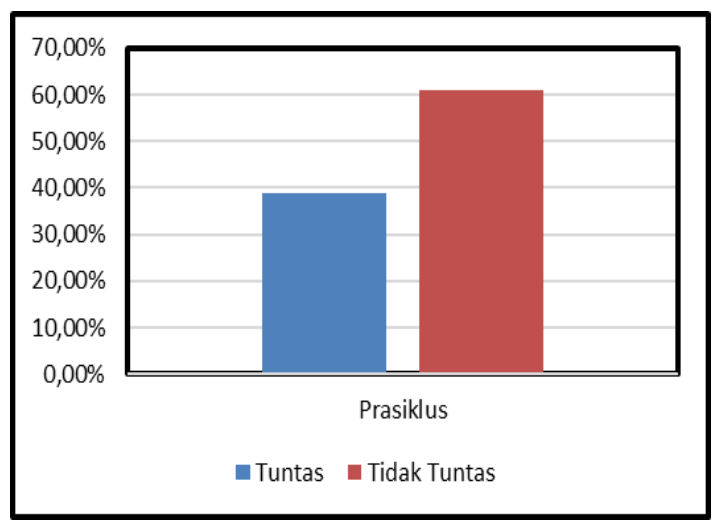

\section{Grafik 1. Persentasi Ketuntasan Belajar Siswa Pada Pra Tindakan}

Berdasarkan data hasil belajar pra tindakan pada materi konsep, pendekatan, prinsip serta aspek geografi, dapat diketahui bahwa hanya 39\% dari jumlah siswa yang tuntas berdasarkan KKM yang mana KKM yang telah ditetapkan dengan nilai $\geq 75$. sedangkan hasil rata rata siswa yang didapat dari keseluruhan jumlah nilai siswa pra tindakan adalah 60,98 . dari hasil tes konsep, pendekatan, prinsip serta aspek geografi dapat disimpulkan bahwa tingkat pengetahuan siswa terhadap materi dasar geografi tergolong rendah. Hasil belajar yang diketahui ini memperlihatkan bahwa siswa belum memahami konsep, pendekatan, prinsip serta aspek geografi dengan baik ini terlihat dari ketuntasan presentase ketuntasan siswa hanya berkisar pada $39,02 \%$ tentunya hasil ini jauh dari kriteria ketuntasan yang ditentukan. Siswa terlihat kesulitan dalam menyelesaikan tes yang dilaksanakan. Model pembelajaran yang diberikan guru sebelum tes pra tindakan adalah model pembelajaran seperti biasanya berbasis ceramah dan tanya jawab.

\section{SIKLUS I}

Berdasarkan permasalahan yang dirumuskan dan melihat dari hasil pra tindakan maka dilakukan siklus I dengan menggunakan model pembelajaran tipe Scramble di kelas X B SMA Negeri 1 Mentebah. Pada siklus I dimulai dengan perencananaan siklus I secara matang berkolaborasi bersama guru geografi. Selanjunya dilakukan pelaksanaan tindakan (action). Pada Tahap ini secara menyeluruh model pembelajaran Scramble digunakan dimulai dengan pembagian kelompok yang dipilih secara acak oleh guru. Diawal pembentukan kelompok, siswa masih belum bisa bekerjasama dan berdiskusi dengan baik. Hal ini dikarenakan guru belum memberikan penjelasan mengenai langkah-langkah pembelajaran scramble yang akan diterapkan dalam pembelajaran. Hal ini memberikan dampak yang kurang baik pada siswa, dimana siswa bingung saat mengerjakan tugas yang diberikan. Pada keseluruhan penggunaan model pembelajaran Scramble, guru belum melaksanakan secara optimal dan hal ini juga turut berdampak pada hasil belajar formatif siswa.

Berdasarkan hasil tindakan siklus I, menunjukkan bahwa hasil belajar formatif siswa pada materi pengantar geografi memperoleh ratarata nilai kelas sebesar 74,76 dengan persentase siswa yang tuntas sebesar 53,66. Hal ini memperlihatkan bahwa terjadi peningkatan namun belum cukup baik karena jumlah siswa yang tuntas belum masuk dalam kriteria ketuntasan yang ditetapkan $\geq 70 \%$. Hal ini pun menjadi landasan untuk melakukan siklus ke II. 


\section{SIKLUS II}

Pelaksanaan siklus II dimulai dengan perencanaan tindakanyang dilaksanakan berkolaborasi bersama guru geografi. Perencanaan tindakan meliputi mempersiapkan RPP, materi dan langkah dalam pelaksanaan model pembelajaran scramble, persiapan evaluasi akhir siklus lengkap dengan kisi-kisi pedoman penskoran, membuat lembar observasi peserta didik dan tutor, dan menyiapkan lembar tugas yang akan dikerjakan siswa.

Pelaksanaaan tindakan siklus II dilaksanakan sesuai dengan Rencana Pelaksaan Pembelajaran (RPP) yang telah dibuat.Selama pelaksaaan pembelajran pada siklus II. Guru sudah menjelaskan secara terperinci mengenai pembelajaran tipe Scramble berisi langkah-langkah pembelajaran serta durasi waktu yang diberikaan pada saat mengerjakan soal. Guru memberikan durasi tertentu untuk pengerjaan soal dan melakukan kegiatan penilaian terhadap hasil kerja siswa, sehingga setiapa anggota saling bekerja sama dengan berdiskusi dalam mengerjakan soal pada lembar tugas yang diberikan guru, dan dapat mengerjakan soal berdasarkan waktu yang telah ditentukan. Guru juga memberikan apresiasi kepada siswa yang berhasil, dan memberikan semangat kepada siswa yang belum cukup berhasil menjawab dengan cepat dan benar, sehingga siswa dapat mengetahui kekurangan dan kelebihan dari hasil tugas yang dikerjakan dan dapat meningkatkan motivasi belajar siswa.

Pada tahap refleksi hasil observsi dan catatan dilapangan di diskusikan Bersama guru untuk mengevaluasi sejah mana peningkakatan tindakan pengajaran yang telah dilakukan. Untuk melihat peningkatan di akhir pertemuan guru memberikan soal tes sebagai evaluasi. Kemudian membandingkan evaluasi pencapaian keberhasilan hasil belajar siklus I dan siklus ke II unruk melihat keberhasilan penggunaan pembelajaran tipe Scramble sebagai upaya meningkatkan hasil belajar formatif siswa.

Hasil belajar Pada siklus II, diperoleh hasil yang jauh lebih baik dimana siswa yang tuntas sebanyak 33 orang atau $80,49 \%$ dan siswa yang tidak tuntas hanya sebanyak 8 orang. Tindakan yang dilakukan bagi sisiwa yang belum tuntas yaitu dengan memberikan bimbingan kepada mahasiswa yang masih belum paham atau masih blama menyerap materi. Adapun hasil tindakan siklus II menunjukan bahwa hasil belajar sudah mecapai indikator yang telah ditentukan yaitu $70 \%$ secara klasikal.

Bedasarkan hasil yang diperoleh dari pelaksanaan dijumpai hal hal yang merupakan aspek positif dari tipe Scramble dalam upaya meningkatkan hasil belajar siswa pada pengantar geografi. Adapun aspek aspek positif yang tercapai dalam pembelajaran tipe Scramble ini diantara nya (a) suasana pembelajaran dirasakan lebih baik dibandingkan siklus I, hal ini tampak dalam hasil observasi pada kegiatan belajar mengajar (b) Hail belajar formatif setelah melalui oembelajaran dengan tindakan kelas mengalami peningkatan pada siklus ke II (c) Guru sudah menjelaskan mengenai pembelajaran tipe Screamble secara terperinci mengenai langkahlangkah yang dilakukan dalam pelaksanaan pembelajaran tipe tersebut seperti menjelaskan kepada siswa mengenai durasi waktu yang diberikan saat mengerjakan soal ataupun tipe soal yang diberikan (d) Guru memberikan durasi tertentu untuk pengerjaan soal dan melakukan kegiatan penilaian terhadap hasil kerja siswa, sehingga setiap anggota saling bekerjasama dan berdiskusi dalam mengerjakan soal pada lembar tugas yang diberikan guru, dan dapat mengerjakan soal berdasarkan waktu yang telah ditentukan guru (e) Guru memberikan apresiasi kepada siswa yang berhasil, dan memberikan semangat kepada siswa yang belum cukup berhasil menjawab dengan cepat dan benar, sehingga siswa dapat mengetahui kekurangan dan kelebihan dari hasil tugas yang dikerjakannya dan dapat meningkatkan motivasi belajarnya, khususnya pada materi Pengantar Geografi. Upaya meningkatkan hasil belajar formarif pada pelaksanaan siklus II sudah menunjukan hasil yang memuaskan dan indicator ketuntasan hasil belajar sudah terapai. Disepakati bahwa pelaksanaan cukup sampai siklus II saja.

\section{PEMBAHASAN}


Pelaksanaan kegiatan tindakan kelas dengan menggunakan pembelajaran tipe Scramble dalam meningkatkan hasil belajar formatif pada dilakukan sebanyak II siklus. Berikut ini penjelasan mengenai penggunakaan pembelajaran tipe Scramble di SMA Negeri 1 Mentebah Kabupaten Kapuas Hulu .

Penggunaan pembelajaran tipe Scramble di kelas X SMA Negeri 1 Mentebah Kabupaten Kapuas Hulu

Penggunaan pembelajatan tipe Scramble dalam upaya meningkatkan hasil belajar formatif siswa. Pelaksanaan kegiatan ini dilakukan dua siklus sesuai dengan rencana pelaksanaan pembelajaran . perencanaan pembelajaran di buat tiga RPP,RPP pertama membuat kegiatan pratindakan disetiap pertemuan, RPP kedua memuat kegiatan siklus I dan RPP ketiga memuat siklus II.

Kegiatan pra tindakan pertemuan ke-1, dilakukan dengan merencanakan rencana pelaksanaan pembelajaran (RPP) dengan menentukakn materi, membuat evaluasi akhir siklus lengkap dengan kisikisi dan pedoman penskoran, membuat lembar observasi untuk peserta didik dan tutor, membuat lembar catatan lapangan tutor dan peserta didik dan menyiapkan lembar tugas untuk penggunaan pembelajaran tipe Scramble.

Kegiatan yang dilaksanakan pada tahap ini adalah melaksanakan pembelajaran yang tertuang dalam RPP. Pelaksanaan dilakukan dalam 2 siklus, masing-masing siklus terdiri dari satu kali pertemuan dengan menggunakan pembelajaran tipe Scramble. Pada tahap ini, peneliti memberikan tes siklus I pada akhir pertemuan ke-1. Peneliti bersama guru juga melakukan refleksi atas pelaksanaan pembelajaran dengan menggunakan pembelajaran tipe Scramble, menghitung hasil tes siklus I.

kegiatan siklus I dilaksanakan pada pertemuan ke-1. Setiap pertemuan memuat kegiatan perencanaan, pelaksanaan tindakan, pengamatan tindakan dan refleksi tindakan. Pada pelaksanaan siklus I ini, penggunaan pembelajaran tipe Scramble belum menunjukkan hasil yang maksimal, dimana dijumpai beberapa kelemahan pada penggunaannya yaitu (a) Guru tidak menjelaskan mengenai pembelajaran tipe Scramble secara terperinci mengenai langkah-langkah yang dilakukan dalam pelaksanaan pembelajaran tipe tersebut seperti menjelaskan kepada siswa mengenai durasi waktu yang diberikan saat mengerjakan soal ataupun tipe soal yang diberikan.(b) Guru tidak memberikan durasi tertentu untuk pengerjaan soal dan tidak melakukan kegiatan penilaian terhadap hasil kerja siswa.(c)Guru tidak memberikan apresiasi kepada siswa yang berhasil, dan memberikan semangat kepada siswa yang belum cukup berhasil menjawab dengan cepat dan benar.(d) Guru tidak mengecek durasi waktu sambil memeriksa pekerjaan siswa dan tidak mengoreksi bersama dengan siswa hasil lembar kerja.

Kekurangan-kekurangan di atas berdampak pada hasil tes yang diberikan pada pertemuan ke-2. Hasil tes menunjukkan siswa yang tuntas atau mencapai nilai di atas 75 hanya sebanyak 22 orang saja $(53,66 \%)$, sedangkan sisanya sebanyak 19 orang $(46,34 \%)$ belum tuntas. Mengingat ketuntasan siswa belum mencapai 75, maka berdasarkan kesepakatan dilanjutkan ke siklus II, dengan memperbaiki kekurangan yang terdapat pada siklus I.

Siklus II dilaksanakan pada pertemuan ke2. Kekurangan yang terdapat pada siklus I, selanjutnya di perbaiki dan diterapkan pada siklus II. Setelah diterapkan, menunjukkan hasil yang baik. Pada proses pembelajaran, siswa mengerti mengenai langkah-langkah pelaksanaan pembelajaran tipe Scramble dan bentuk soal tipe Scramble, setiap anggota kelompok saling bekerjasama dan berdiskusi dalam mengerjakan soal pada lembar tugas yang diberikan guru, dan dapat mengerjakan soal berdasarkan waktu yang telah ditentukan guru. Siswa dapat mengetahui kekurangan dan kelebihan dari hasil tugas yang dikerjakannya dan dapat meningkatkan motivasi belajarnya, khususnya pada materi Pengantar Geografi, siswa juga menerima hasil dari penilaian guru terhadap soal yang dibagikan dan dapat mengetahui serta memperbaiki nilai-nilai yang masih rendah.

Peningkatan Hasil belajar dengan meggunakan pembelajaran Tipe Scramble di kelas X SMA Negeri 1 Mentebah Kabupaten Kapuas Hulu 
Hasil belajar siswa di kelas $\mathrm{X}$ tampak mengalami peningkatan setelah dilaksanakan siklus I dan siklus II. Peningkatan tersebut dapat dilihat hasi tes disetiap akhir siklus I dan diakhir siklus II yang diberikan setiap akhir pemeblajaran. Rekapitulasi perbandingan tes hasil belajar di tampilkan pada tabel dibawah ini:

Tabel 2. Rekapitulai Hasil Belajar Siswa dari Pra Tindakan, Siklus I, Siklus II

\begin{tabular}{|c|c|c|c|c|c|}
\hline \multirow[b]{2}{*}{ Siklus } & \multirow[b]{2}{*}{$\begin{array}{l}\text { Jmlh } \\
\text { Siswa }\end{array}$} & \multicolumn{2}{|c|}{ Nilai } & \multirow{2}{*}{$\begin{array}{l}\text { Nilai } \\
\text { Rata } \\
\text {-rata }\end{array}$} & \multirow{2}{*}{$\begin{array}{c}\text { Persentase } \\
\text { Ketuntasan } \\
(\%)\end{array}$} \\
\hline & & $\leq 75$ & $\begin{array}{l}\geq \\
75\end{array}$ & & \\
\hline Pra Tindakan & 41 & 25 & 16 & 68,41 & 39,02 \\
\hline Siklus I & 41 & 19 & 22 & 74,76 & 53,66 \\
\hline Siklus II & 41 & 8 & 33 & 85,00 & 80,49 \\
\hline
\end{tabular}

Berdasarkan data dari hasil pengamatan terhadap guru dalam melaksanakan penggunaan model pembelajaran tipe Scramble setiap siklus nya menunjukan peningkatan, berdasarkan hasil persentasi lembar observasi guru pada siklus 1 hanya mencapai $64 \%$ bedasarkan hasil observasi hal ini dikarenakan Setelah selesai menjelaskan materi, guru tidak membagikan lembar kerja dengan jawaban yang diacak susunannya. Guru tidak menyajikan materi sesuai topik yang akan disampaikan, tidak membentuk siswa dalam beberapa kelompok terdiri dari 5-6 anggota dalam satu kelompok. Akibatnya siswa tidak dibentuk secara berkelompok yang dipilih secara acak oleh guru.

Guru tidak memberikan durasi tertentu untuk pengerjaan soal dan tidak melakukan kegiatan penilaian terhadap hasil kerja siswa. Akibatnya setiap anggota tidak saling bekerjasama dan berdiskusi dalam mengerjakan soal pada lembar tugas yang diberikan guru, siswa tidak mengerjakan soal berdasarkan waktu yang telah ditentukan guru.

Guru tidak memberikan apresiasi kepada siswa yang berhasil, dan memberikan semangat kepada siswa yang belum cukup berhasil menjawab dengan cepat dan benar. Akibatnya siswa yang berhasil mengisi lembar tugas dengan benar, tidak menerima apresiasi dari guru dan siswa yang belum cukup berhasil menjawab dengan cepat dan benar, tidak menerima semangat dan bimbingan dari guru, juga belum nampak. Hal ini dapat mengakibatkan siswa tidak mengetahui kekurangan dan kelebihan dari hasil tugas yang dikerjakannya, sehingga dapat menurunkan motivasi belajarnya, khususnya pada materi Pengantar Geografi.Guru tidak memeriksa pekerjaan siswa dan tidak mengoreksi bersama dengan siswa hasil lembar kerja. Akibatnya siswa tidak menerima hasil dari penilaian guru terhadap soal yang dibagikan.

Pada siklus ke II hasil lembar observasi guru menunjukan terjadinya peningkatan dengan presensi ketuntasan mencapai $81 \%$.hasil tersebut menunjukan guru dalam pelaksanaan pembelajarannya berjalan dengan efektif pada penggunaan model pemebelajaran tipe Scramble dalam penyajian materinya.

Hasil observasi guru dan siswa pada pertemuan kedua siklus II menunjukkan peningkatan yang baik sekali, dimana pada proses pembelajaran, guru sudah menjelaskan mengenai pembelajaran tipe Scramble secara terperinci mengenai langkah-langkah yang dilakukan dalam pelaksanaan pembelajaran tipe tersebut seperti menjelaskan kepada siswa mengenai durasi waktu yang diberikan saat mengerjakan soal ataupun tipe soal yang diberikansiswa mengerti mengenai langkahlangkah pelaksanaan pembelajaran tipe Scramble dan bentuk soal tipe Scramble, setiap anggota kelompok saling bekerjasama dan berdiskusi dalam mengerjakan soal pada lembar tugas yang diberikan guru, dan dapat mengerjakan soal berdasarkan waktu yang telah ditentukan guru.

Guru sudah menjelaskan mengenai pembelajaran tipe Scramble secara terperinci mengenai langkah-langkah yang dilakukan dalam pelaksanaan pembelajaran tipe tersebut seperti menjelaskan kepada siswa mengenai durasi waktu yang diberikan saat mengerjakan soal ataupun tipe soal yang diberikan. Guru memberikan durasi tertentu untuk pengerjaan soal dan melakukan kegiatan penilaian terhadap hasil kerja siswa, sehingga setiap anggota saling bekerjasama dan berdiskusi dalam mengerjakan soal pada lembar tugas yang diberikan guru, dan 
dapat mengerjakan soal berdasarkan waktu yang telah ditentukan guru.

Guru juga memberikan apresiasi kepada siswa yang berhasil, dan memberikan semangat kepada siswa yang belum cukup berhasil menjawab dengan cepat dan benar, sehingga siswa dapat mengetahui kekurangan dan kelebihan dari hasil tugas yang dikerjakannya dan dapat meningkatkan motivasi belajarnya, khususnya pada materi Pengantar Geografi. Selain itu, guru juga sudah mengecek durasi waktu sambil memeriksa pekerjaan siswa dan mengoreksi bersama dengan siswa hasil lembar kerja, sehingga siswa menerima hasil dari penilaian guru terhadap soal yang dibagikan dan dapat mengetahui serta memperbaiki nilai-nilai yang masih rendah.

Efek positifnya adalah siswa dapat mengetahui kekurangan dan kelebihan dari hasil tugas yang dikerjakannya dan dapat meningkatkan motivasi belajarnya, khususnya pada materi Pengantar Geografi, siswa juga menerima hasil dari penilaian guru terhadap soal yang dibagikan dan dapat mengetahui serta memperbaiki nilai-nilai yang masih rendah. Suasana pembelajaran dirasakan lebih baik dibandingkan siklus I, hal ini tampak dalam hasil observasi pada kegiatan belajar mengajar. Hasil belajar formatif siswa setelah melalui pembelajaran dengan tindakan kelas dengan menggunakan pembelajaran tipe Scramble pada siklus I dan siklus II mengalami peningkatan

Berdasarkan data hasil belajar siswa sebagai pengukur ketercapaiaan dan peningkatan dalam pelaksanaan penggunaan pembelajaran tipe Scramble dalam upaya meningkatkan hasil belajar formarif siswa kelas XB SMA Negeri 1 Mentebah Kabupaten Kapuas Hulu, dilaksanakan melalui penelitian tindakan kelas. Pelaksanaan penelitian dilakukan melalui dua siklus yaitu siklus I dan siklus II.

Adapun gambaran persentase ketuntasan pada pratindakan, siklus 1 dan siklus 2 dapat dilihat pada diagram sebagai berikut :

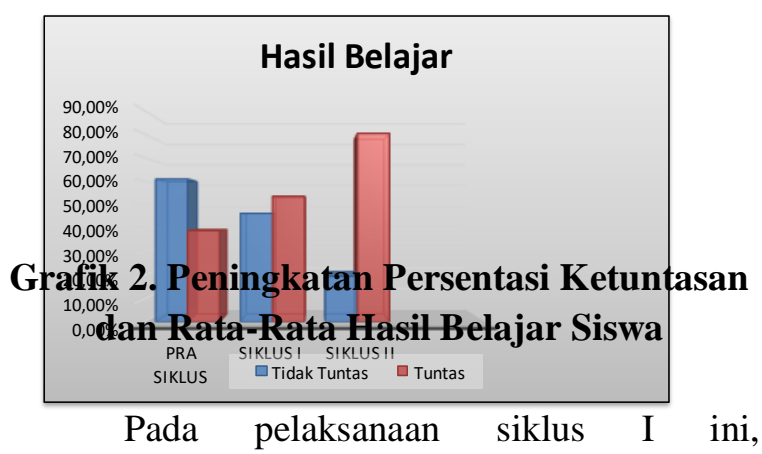
penggunaan pembelajaran tipe Scramble belum menunjukkan hasil yang maksimal, dimana dijumpai beberapa kelemahan pada penggunaannya. Hasil perhitungan pada siklus I dan siklus II, dapat dilihat perkembangan hasil belajar yang diperoleh pada saat tes siklus I dan tes siklus II. Siswa yang mengalami ketuntasan belajar atau yang memperoleh nilai ketuntasan pada saat sebesar 39,02\% dan siswa yang tidak tuntas $60,98 \%$ dengan nilai rata-rata sebesar 68,41. Pada siklus I dapat di lihat hasil ketuntasan belajar siswa mengalami peningkatan sebesar 53,66\% dan jumlah siswa yang tidak tuntas sebesar $46,34 \%$ dengan nilai rata-rata sebesar 74,76. Pada siklus II, diperoleh hasil yang jauh lebih baik dimana siswa yang tuntas $80,49 \%$ dan siswa yang tidak tuntas $19,51 \%$, dengan nilai rata-rata sebesar 85,00. Bedasarkan hasil peneltian ini bahwa pembelajaran tipe Scramble terdadapat peningkatan $85 \%$, dan sudah mencapai indicator keberhasilan, maka Dengan demikian berdasarkan kesepakatan peneliti dan guru Geografi, maka penggunaan pembelajaran tipe Scramble dalam upaya meningkatkan hasil belajar formarif cukup sampai siklus II.

\section{KESIMPULAN}

Berdasarkan hasil pengolahan data, dapat disimpulkan bahwa hasil persentasi lembar observasi guru dengan menggunakan model pembelajaran tipe Scramble, pada siklus I hanya mencapai $64 \%$ dan pada siklus ke II hasil lembar observasi guru menunjukan terjadinya peningkatan dengan presensi ketuntasan mencapai $81 \%$. Hasil perhitngan Persentase pada prasiklus sebesar $53,66 \%$ dengan rata-rata nilai 68,41.Pada siklua I Persentase ketuntasan sebesar $53,66 \%$ dengan rata- rata nilai 74,76 . Persentase 
siklus ke II sebesar $80,49 \%$ dengan nilai rata-rata $85 \%$, dengan demikian berdasarkan kesepakatan peneliti dan guru Geografi, maka penggunaan pembelajaran tipe Scramble dalam upaya meningkatkan hasil belajar formarif cukup sampai siklus II.

\section{DAFTAR PUSTAKA}

Djamarah, S. B. (2002). Strategi Belajar Mengajar. Jakarta: Rineka Cipta.

Huda, M. (2013). Model -Model Pengajaran dan Pembelajaran . Yogyakarta : Pustaka Pelajar

Lestari, F. I., \& Sriwanto, S. (2015). Upaya Meningkatkan Aktivitas dan Prestasi Belajar Peserta Didik pada Mata Pelajaran Geografi Melalui Model Pembelajaran Scramble Kelas X9 di MAN Purwokerto 1. IV, 23-30. http://jurnalnasional.ump.ac.id/index.php/GeoE dukasi/article/view/534.

Lisa, J., Ariesta, R., \& Purwadi, A. (2018). Analisis Interaksi Guru dan Siswa dalam Pembelajaran Bahasa Indonesia di Kelas VII SMP Negeri 15 Kota Bengkulu . Jurnal Ilmiah Korpus , 270282.

Purwanto. (2010). Evaluasi Hasil Belajar. Yogyakarta : Pustaka Pelajar.

Sudjana, N. (2010). Penilaian Hasil Proses Belajar Mengajar. Bandung : Remaja Rosdakarya. 